\title{
Does Size Favor Dividends or Retained Earnings?
}

\author{
Bashar K Abu khalaf ${ }^{1}$ \\ ${ }^{1}$ School of Business, The University of Jordan, Amman, Jordan \\ Correspondence: Bashar Abu Khalaf, School of Business, The University of Jordan, Amman, Jordan. Tel: \\ 962-77-555-8777. \\ Received: March 31, 2016 \\ Accepted: April 14, 2016 \\ Online Published: April 18, 2016 \\ doi:10.5430/ijfr.v7n2p225 \\ URL: http://dx.doi.org/10.5430/ijfr.v7n2p225
}

\begin{abstract}
The relationship between dividend, retained earnings and stock returns is one of the debated topics addressed by the researchers; different theories used in order to examine empirically the relationship by using different models. This study collected the data of 85 companies (52 industrial and 33 services) for the period 2000-2014 and the results show that there is a significant relationship between dividend policy, retained earnings and share price taking into consideration that the size of the firm in Jordan affects the preference of investors significantly.
\end{abstract}

Keywords: dividend policy, retained earnings, size, Amman stock exchange

\section{Introduction}

For the growth of a business, a continuous support from investors is essential. They provide a strong financial support to organizations as important stakeholders. The strength of an organization, in today's international business, is heavily depended upon the strength of its investors. This fact emphasizes that if a business owner wants to register his presence in the industry for long term, he must pay attention to the values provided by the investors to the business. Dividend is a tool that helps the management in achieving its primary objective targeting at the maximization of the company's market value. As an extension of the efforts of researchers in filling the gab of this area in the Jordanian market, this study comes to test the relationship between retained earnings, dividends and stock returns for the service and industrial companies in Jordan, to examine whether the adoption of investors to the information included in the cash dividend of profits in making their investment decisions vary. Then the size effect on this relationship will be explored in two scenarios, the first scenario is when the company sticks on the last year payment, while the other one is when the company decides to increase or decrease dividends.

Two models are adopted in this empirical paper, the first one is the Friend \& Puckett's (1964) model and the second is the interaction dummy form model, which is developed on the basis of the first model (mainly to reveal if the size of the company affect the relation between dividend, retained earnings and share price in two different scenarios; the increase or decrease of dividends). Different econometric techniques (e.g. pooled and panel data) were used for the analysis of the models. Fixed or random effect is usually used for the estimation of panel data, while it serves capturing the impact of firm and time specific heterogeneities and in order to identify the best technique Hausman's test is applied.

The data has been collected from the firm's annual reports and the publications of ASE. The total sample consisted of 85 listed companies, out of which 52 were industrial and 33 were service, for the time period (2000-2014). This empirical paper will start by analyzing the theoretical background, for example the different theories explaining the relation between dividend, retained earnings and share price and more specifically the signaling theory and the free cash flow hypothesis. Then we move to the model specification where the models used will be explained and specified. Finally, we analyze the results of the two models and provide the conclusion.

\section{Theoretical Background}

The maximization of share price is the basic concern of all companies, and has led to the documentation of different theories that try to investigate the relation of dividend policies, retained earnings and stock returns. The Dividend Irrelevance Theory introduced in 1961 by Miller \& Modigliani (M\&M) supports the absence of costs related to transactions and taxes, where no one can affect the price of a security; all individuals expect to have similar upcoming investments and profit. Therefore, paying dividends would not affect the firm's value and its share price (Ross et.al. 1999). Consequently, what determine the firm value are the profits achieved and the risk of assets but not the different combinations of retained earnings and dividends. The proof of irrelevancy of dividend has been justified 
by the offset between dividend payment and capital loss. The relation between future selling price and current income could be depicted in any increase/decrease of dividends. Despite the fact that, the prefect market described by M\&M does not exist in reality and has not been justified empirically, other theories that take into consideration that there is no perfect market, were based on the Dividend Irrelevance Theory.

For example one of the imperfections of the market that has led to the development of different theories in finance is the signaling theory, which is also called the information content of dividend hypothesis. Based on the signaling theory, dividend payments are usually used to send information in an indirect way about the company so that the managers show a confident vision about the future earnings and the stability of the cash flow needed. Thus, the shareholders will react to the declaration of dividends which would lead to changes in the share price. However, research has not been clear regarding the effect of the information delivered by the declaration of dividends on share price and if the investors prefer companies to retain profits instead of paying dividends, especially in Jordan.

Other theories started building on the assumptions of signaling theory, such as the cash flow hypothesis, also called cash flow signaling theory. Among those who developed the cash flow hypothesis were John \& Williams (1985), Bhattacharya $(1979,1980)$ and Miller \& Rock $(1985)$, who theorized that the decision taken by managers to increase or decrease dividends would affect the company's cash flow at a certain cost. Miller \& Rock (1985) investigated the effect of dividend payment on the company's cash flow. They assumed that the information about the internal cash flow of the company is not fully shred to all the interested parties, but the information regarding the assets value and investments of the company is available to everyone. They argued that the probability of paying dividend is highly correlated with the company's cash flow other factors remaining constant. In other words, when a company declares paying dividends more than predicted in the market then it signals the confidence of managers about the future cash flows which will result in an increase in share price. Therefore, the cash flow signaling theory assumed that an increase/decrease in dividend payment will result in an increase/decrease in share prices, taking into consideration that the level of dividends is related to the level of stability of earnings which impacts the share price.

On the other hand, the Free Cash Flow Hypothesis was introduced by Jensen (1986) who explained that the free cash flow is the remaining cash after accepting all positive net present value projects. He discussed that the movement of share price can be clarified by the different interest of managers and shareholders about the dividend payment. In other words, this theory expects an upward movement in the share price when there is an increase in dividend, since it relates the decrease of dividends to high free cash flow. Further, Jensen (1986) discussed, that managers get incentives to enlarge the size of their companies, for increasing the resources and their compensation because all these factors are closely associated with the company's size. Therefore, availability of cash in excess can lead the manager towards the problem of over investment i.e. investing in the non-profitable project. The management should extract some excessive funds from the free cash flow for coping up with the problems of over investment. So a good option would be to increase the dividend payment to decrease the free cash flow under the control of manager. Control on the free cash flow prevents the investment in the projects which have negative NPV and also reduces the agency costs between managers and shareholders.

Moreover, Easterbrook (1984) introduced a new theory called the agency cost theory which concluded similar assumption. He argued that when managers are not the owners of the company this will give them the right to use the company's assets to their own benefit. Furthermore, he considered that dividends have to be used as a technique to reduce the free cash flow. For example, when the company pays dividends this will lead to the decrease of available funds in the company. Consequently, the possibility of managers using the free cash for their own benefit decreases dramatically. In this case, the agency cost theory relates the increase in dividend positively to a firm's value and its share price.

\section{Model Specification}

The relation between dividend, retained earnings and share prices has been of major interest of Gordon (1959), who specifies that the main reason to make the investors usually be interested to buy a certain share instead of any other is the good return that can be generated by that share in terms of dividend. Following the rationale of Gordon (1959) the relationship between dividend, retained earnings and share price can be estimated as follows:

$$
P_{i, t}=\alpha_{1}+\alpha_{1} D_{i, t}+\alpha_{2} R_{i, t}+\varepsilon_{i}
$$

Where,

$P_{i, t}$ is the share price for firm $\mathrm{i}$ in period $\mathrm{t}, D_{i, t}$ is the dividend for firm $\mathrm{i}$ in period $\mathrm{t}, R_{i t}$ is the retained earnings for firm $\mathrm{i}$ in period $\mathrm{t}$. 
Gordon concluded that the impact of retained earnings on the market share price is lower than the impact of dividends. Moreover, the argument raised by Gordon suggested that the increase of the required rate of return on a stock would be associated with the proportion of retained earnings. Fisher's (1961) and Gordon's (1963) results were in line with Gordon (1959) that dividends affect the market share price more than retained earnings. However, equation (1) was criticized due to the fact that the risk of different firms of different industries was neglected, which leads to biased dividend coefficients $\alpha_{1}$.

Friend and Puckett (1964) also investigated the impact of retained earnings and dividend on the stock market price. They concluded that the dividend has a greater effect on the share price than retained earnings. Friend and Puckett (1964) estimated the impact of retained earnings and dividend on the market share price as follows:

$$
M P S_{, t}=\alpha_{1}+\beta_{1} D P S_{, t}+\beta_{2} R E_{i, t}+\varepsilon_{i}
$$

Where:

$M P S_{i, t}$ is the market price per share, $D P S_{i, t}$ is the dividend per share, $R E_{i t}$ is the retained earnings per share.

The model developed by Friend and Puckett (1964) faced similar criticism with Gordon's. The main concern was the omitted variables' problem which leads to statistical bias in estimating the equation, for example the assumption that either risk is held constant or that paying dividend is uncorrelated with risk and that expectations of growth are determined solely by the relative amount of current earnings retention or alternatively that growth from other sources is uncorrelated with the relative amount of retention. In an attempt to overcome neglecting the risk in the equation, too many researchers included a risk variable in the regression. One of the measures used as a proxy for the factor of risk is the earnings fluctuations variable, which is greatly subjective by cyclical factors in the company's operating performance and has not solved the problem of risk properly.

Since researchers acknowledged that there is a positive correlation between the quality of the stock and the market share price, dividends and earnings, then we can understand that a high quality stock can increase the return for investors. Consequently, the relation between the investment quality and the regression weights might exaggerate the existence of regression bias. In some studies the regression variable was converted into logarithms to reduce the weight problem faced in the regression. In addition, a good point to be taken into consideration is the total effect of firm. Direct measurement of these effects is not possible since the effect of the firm can be both cumulative and constant. To solve this problem, a new variable should be included in the regression equation which is the lagged price earnings $(\mathrm{PE})_{\mathrm{t}-1}$.

Following the rationale of Pradhan (2003) the relationship between dividend, retained earnings and market price can be estimated as follows:

$$
M P S_{, t}=\alpha_{1}+\beta_{1} D P S_{1, t}+\beta_{2} R E_{i, t}+\beta_{3} P E_{t-1}+\varepsilon_{i}
$$

Where,

$M P S_{i, t}$ is the market price per share, $D P S_{i, t}$ is dividend per share, $R E_{i t}$ is the retained earnings per share, $P E_{t-1}$ is the lagged price earnings ratio

The signaling theory suggests that firms following stable dividend policy signal the confidence of continuing stable level of cash flow which could be translated as lower business risk and low level of cash flow uncertainty. On the contrary, an unstable dividend policy is an indicator of fluctuation of cash flows and risk which impose them to demand more returns for their investments (Kale and Noe, 1990). In addition, Jordanian firms follow stable dividend policy and the size of the firm affects their dividend policy. Larger firms in Jordan show more tendency of making adjustment in their dividend payout ratio than smaller firms. Brigham \& Ehrhardt (2005) also supported this view, stating that investors generally prefer the company which gives stable and dependable dividends.

This paper tests model (3) and modifies it by introducing the interaction dummy form to estimate the relation between dividends, retained earnings, the size effect of Jordanian firms and the Market share price. Two models will be developed; the first model to test the relationship between dividends, retained earnings and share price while applying the interaction dummy form with size when there is an increase/decrease in dividends. The second model will test the same effect of relationship but when there is no change in dividends. The interaction between dividend and size can help in testing whether the size of companies (large/small companies who change or not their dividends over time) affects share price. The research includes firms from two Jordanian sectors - the service and industrial 
sectors. The reason that this technique is better than the classic ones is that is shows the source of difference; it investigates whether the size of the firm has an effect on the relationship between dividend, retained earnings and the share market price.

The first model of the interaction form when dividend changes can be written as follows:

$$
M P S_{, t}=\alpha_{1}+\beta_{1} D P S_{i, t}+\beta_{2} R E_{i, t}+\beta_{3} P E_{t-1}+\beta_{4} D^{\text {size }}+\beta_{5}\left(D^{\text {size } *} D P S_{i, t}\right)+\beta_{6}\left(D^{\text {size } *} R E_{i, t}\right)+\varepsilon_{i}
$$

When:

$$
D P S_{i, t}>D P S_{i, t-1} \text { or } D P S_{i, t}<D P S_{i, t-1}
$$

Where:

$D P S_{i, t}, \quad R E_{i, t}$ and $P E_{\mathrm{i}, \mathrm{t}-1}$ are defined in equation (3) and $D P S_{i, t-1}$ is the lagged dividend per share $D^{\text {size }}$ is a dummy variable which equals one for the firms that have natural logarithm of total assets greater than the median, and equals zero otherwise (i.e. zero to the firms that have natural logarithm of total assets lower than the median).

The interaction dummy term variables are constructed by multiplying $D^{\text {size }}$ by $R E_{i, t}$ and $D P S$ i,t. In Equation (4) above, $\beta 5$ and $\beta 6$ provide the amount of difference. As a result, and for the difference to exist, $\beta 5$ and $\beta 6$ should be statistically significant irrespectively of the coefficients signs.

The second model of interaction form when there is no change in dividend per share can be written:

$$
M P S_{, t}=\alpha_{1}+\beta_{1} D P S_{, t}+\beta_{2} R E_{i, t}+\beta_{3} P E_{t-1}+\beta_{4} D^{\text {size }}+\beta_{5}\left(D^{\text {size } *} D P S_{i, t}\right)+\beta_{6}\left(D^{\text {size } *} R E_{i, t}\right)+\varepsilon_{i}
$$

When:

$D_{i, t}=\operatorname{DPS}_{i, t-1}$

Where:

$D P S_{i, t}, \quad R E_{i, t}$ and $P E_{\mathrm{i}, \mathrm{t}-1}$ as defined in expression (3) and $D P S_{i, t-1}$ is the lagged dividend per share

$D^{\text {size }}$ is a dummy variable which equals one for the firms that have natural logarithm of total assets greater than the median, and equals zero otherwise (i.e. zero to the firms that have natural logarithm of total assets lower than the median).

The interaction variables are constructed by multiplying $D^{\text {size }}$ by $D P S_{i, t}$ and $R E_{i, t}$. In Equation $5, \beta_{5}$ and $\beta_{6}$ provide the effect of size on the relationship. Therefore, for the difference to exist, $\beta_{5}$ and $\beta_{6}$ should be statistically significant regardless of the coefficients signs.

\section{Estimation Results}

The two sub-sections below will hold the discussion of the results for the three estimated regressions for the Jordanian nonfinancial data during the period 2000-2014. The first section will present the result of equation (3), which describes the relationship between dividends, retained earnings and share price. The second section will present and explain the results based on the interaction dummy form model. The model investigated if the size of the company would affect the relationship between dividend, retained earnings and share price in the condition of the change of dividends. The last section also explains the results for the same model but with the condition of the stickiness of dividends. 


\subsection{Estimation Results of Model 3}

The results for the first regression that shows the relationship between dividends, retained earnings and share price are given in Table 1. The significance of Hausman test suggests that the fixed effect model is the best specification to test the equation. The dependent variable is market price per share $M P S_{i, t}$ and the explanatory variables are retained earnings per share $R E_{i . t}$, dividend per share $D P S_{i . t}$ and lagged price earnings ratio $P E_{i, t-1}$. The model is also significant as the null hypothesis that all slope coefficients are jointly zero is rejected at the $1 \%$ level.

Table 1. The estimation results of Expression 3

\begin{tabular}{ll} 
& Dependent Variable: \\
\hline Independent & Expression \\
Variable & 2 \\
\hline $\mathrm{DPS}$ & 0.292 \\
& $(0.003)$ \\
\hline $\mathrm{RE}$ & 0.202 \\
& $(0.000)$ \\
\hline PE $\mathrm{i}, \mathrm{t}-1$ & 0.000 \\
& $(0.935)$ \\
\hline Intercept $(\alpha 1)$ & -0.122 \\
& $(0.000)$ \\
\hline R2 & 0.446 \\
P-value & $(0.00)$ \\
$\mathrm{N}$ & 765 \\
\hline Hausman Test & 12.68 \\
\hline
\end{tabular}

Note: First value for each estimate is the coefficient and $t$-statistics are in the parentheses. $\mathrm{RE}_{\mathrm{i}, \mathrm{t}}$ : retained earnings per share. DPS $\mathrm{i}_{\mathrm{i}, \mathrm{t}}$ is the dividend per share. $\mathrm{PE}_{\mathrm{i}, \mathrm{t}-\mathrm{l}}$ Lagged Price earnings ratio

The fixed effect results show that $44.65 \%$ of the market share price can be explained by the explanatory variables (retained earnings and dividend per share). The p-value is significant; representing that at $1 \%$ of significance the coefficients of the explanatory variables in the model are significantly different from zero. The dividend per share coefficient is $(0.292)$ positive and significant at $1 \%$. In addition, the retained earnings coefficient is also significant at $1 \%$ level and positive (0.202). Since the coefficient of dividend per share is higher than the coefficient of retained earnings then we can conclude that the investors in the nonfinancial Jordanian firms prefer dividend over retained earnings. In other words, the dividend per share explains the market share price better than the retained earnings.

This result is consistent with investigations applied on developed and developing markets. For example, the chemical industry in the study of Friend \& Puckett (1964) reported a coefficient of 27.72 for dividend per share and 13.15 for the retained earnings which confirms the power of dividends over retained earnings. In another study Khan et.al., (2011) investigated the firms in the Bangladeshi market (DSE) and he also found stronger impact of dividends than retained earnings on market share price. (The dividend per share coefficient was 2.072 compared to 1.701 of retained earnings).

\subsection{Estimation Results of Model 4 and 5}

The estimation results of equations (4) and (5) are presented in the Table 2. The results are based on a total sample of 85 companies in the Jordanian market, and report the Hausman Test as insignificant so that the expression with random effects is found as the best specification for both regressions. The dependent variable is market price per 
share $M P S_{i, t}$ and the explanatory variables are retained earnings per share $R E_{i . t}$, dividend per share increased $D P S_{i, t}$ and lagged price earnings ratio $P E_{i, t-1}$. The interaction dummy term variables are constructed by multiplying $D^{\text {size }}$ by $R E_{i, t}$ and $D P S_{i, t}$. The model is also significant as the null hypothesis that all slope coefficients are jointly zero is rejected at the $1 \%$ level. Equation (4) tests the relationship between dividend, retained earnings and market share price interacting with size when the dividend changes while equation (5) tests the same equation with same variables but when dividend decreases.

Table 2. The estimation results of Equations 4 and 5

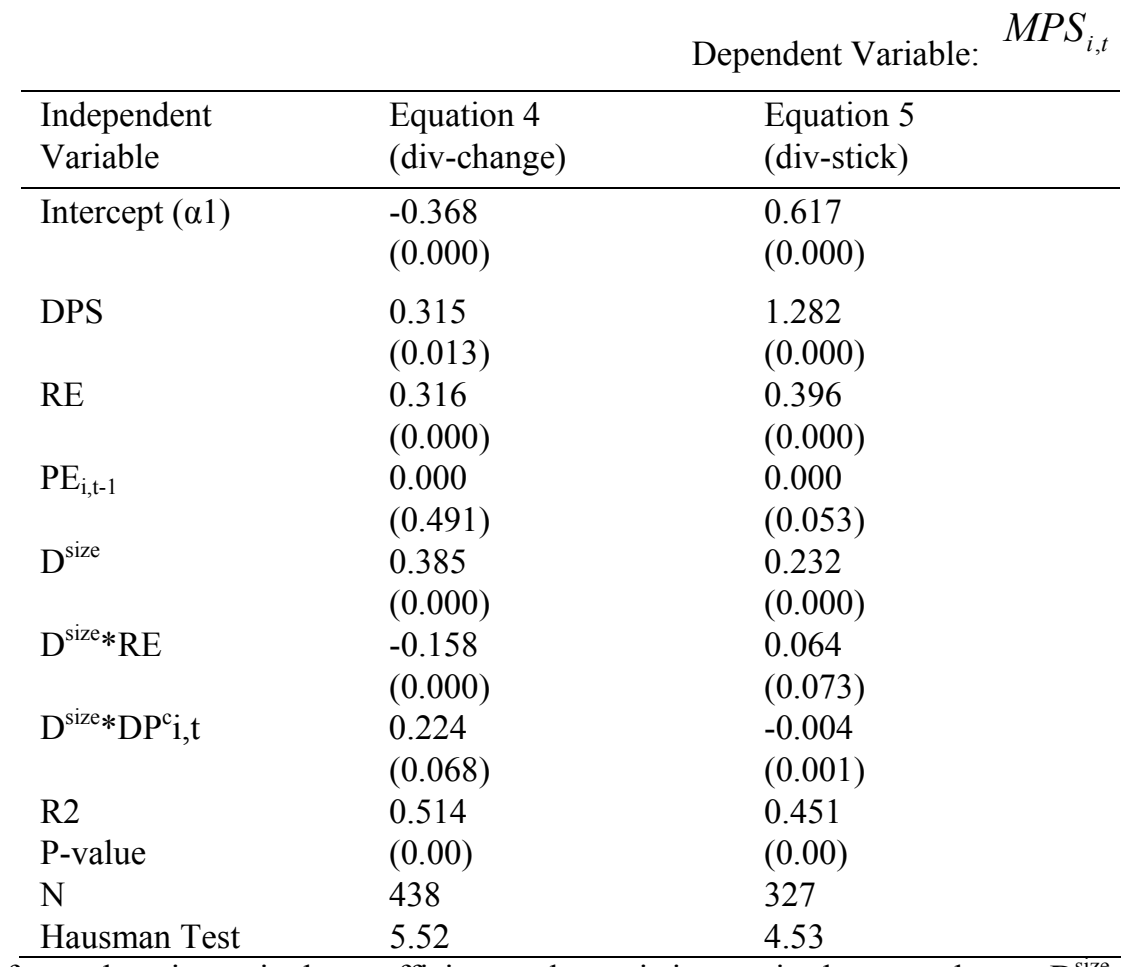

Note: First value for each estimate is the coefficient and t-statistics are in the parentheses. $\mathrm{D}^{\text {size }}$ : a dummy variable which equals one for $\mathrm{D}^{\text {size }}>0$ zero otherwise. $\mathrm{D}^{\text {size }} *$ REit: the interaction dummy variable. $\mathrm{D}^{\text {size }} *$ DPSit is the interaction dummy variable.

\subsubsection{Equation 4}

Model 4 empirically investigate the non-financial companies of the ASE listed firms and the estimation results of the interaction dummy form model support the hypothesis that the large and small Jordanian firms possess different dividend policy behaviors, where the estimated coefficients and its interactions dummy form are found to be statistically significant at $1 \%$ level.

More specifically, the results above (Table 2) show that the large and small Jordanian firms have different effect on share price when companies change their dividend payments. The estimated coefficients on $D P S_{i, t}$ and its interactions dummy form ( $D^{\text {size } * D P S i}{ }_{i, t}$ ) are found to be statistically significant at $1 \%$ and $10 \%$ level 
respectively. In addition, the estimated coefficients on $R E_{i, t}$ and its interactions dummy form ( $D^{\text {size } * R E i}$ i,t $)$ are found to be statistically significant at $1 \%$ level.

The results demonstrate that the market share price of large firms is more sensitive to dividend change 0.539 $(0.315+0.224)$ and less sensitive to retained earnings $0.158(0.316-0.158)$. Though, the higher coefficient of the change in dividend per share indicates that the large listed Jordanian companies' investors prefer dividends more than retained earnings. This result comes in line with prior research done on the US market; where Fama et al. (1969) and Petit (1972) proved empirically that the change in dividends normally has a significant and positive relationship to the market share price.

On the other hand, the market share price of small firms seems to have the same sensitivity for both the change in dividend per share and retained earnings. The reported coefficients for the change in dividend per share and retained earnings are the same (0.31) which indicated that the Jordanian investors prefer both factors when investing in small firms. This result comes to an agreement with the signaling theory, dividend payments are usually used to send information in an indirect way about the company so that the managers show a confident vision about the future earnings and the stability of the cash flow needed. Thus, the shareholders will react to the declaration of dividends which would lead to changes in the share price.

Moreover, the positive estimated coefficient implies that the change in dividends for the large firms affects the firm market share price more than the small firms, and this also implies that the investors prefer dividend more than retained earnings in large firms' more than small firms. The estimated coefficient for the large firms who change their dividend is calculated to be $0.539(0.224+0.315)$, while it is 0.315 for the small firms.

\subsubsection{Equation 5}

The estimation results of the interaction dummy form model support the hypothesis that the large and small Jordanian firms possess different dividend policy behaviors, where the estimated coefficients and its interactions dummy form are found to be statistically significant at $1 \%$ level.

More specifically, the results above (Table 2) show that the large and small Jordanian firms have different effect on share price when companies stick their dividend payments. The estimated coefficients on $D P S_{i, t}$ and its interactions dummy form $\left(D^{\text {size }} * D P S i{ }_{i, t}\right)$ are found to be statistically significant at $1 \%$ and $10 \%$ level respectively. In addition, the estimated coefficients on $R E_{i, t}$ and its interactions dummy form ( $D^{\text {size } * R E i}$ i,t $)$ are found to be statistically significant at $1 \%$ level.

The results demonstrate that the market share price of large firms is more sensitive to dividend change 1.346 $(1.282+0.064)$ and less sensitive to retained earnings $0.392(0.396-0.004)$. Though, the higher coefficient of the stable dividend per share indicates that once more the large listed Jordanian companies' investors prefer dividends more than retained earnings although the dividend stayed the same. This result comes in line with the findings of chapter three, where it was concluded that the Jordanian firms follow stable dividend policy and that the size of the firm affects the dividend policy in Jordanian firms. (The larger firms in Jordan show more tendency of making adjustment in their dividend payout ratio than smaller firms).

Similarly, the market share price of small firms seems to be more sensitive for both the stable dividend per share and less sensitive for retained earnings. The reported coefficients for the stable dividend per share and retained earnings are the same (1.282) and (0.396) respectively which indicated that the Jordanian investors prefer dividends when investing in small firms.

Moreover, the positive estimated coefficient implies that the stable dividends for the small firms affects the firm market share price less than the large firms, and this also implies that the investors prefer dividend more than retained earnings in large firms' more than small firms. The estimated coefficient for the large firms who stable their dividend is calculated to be $1.346(1.282+0.064)$, while it is 1.282 for the small firms.

\section{Conclusion}

This paper investigated the relationship between dividend, retained earnings and share price in special reference to two industries the industrial and service companies that are listed on the ASE. This paper provides assistance to the investors in order to make their investment decision correctly. The efficiency of the financial market depends upon 
the awareness of the investors. This study is also very beneficial for the company's management and financial managers because it provides a significant assistance to them in the determination of their dividend policies. Through the right dividend policy, an organization can increase the market value of its stock in the financial market and maximize the wealth of its shareholders.

This paper found a significant impact of size in the relationship between dividend, retained earnings and market share price. Size was found to affect the market share price when the companies stable or change their dividends. We had an interesting result that investors attracted to small firms prefer both the retained earnings and dividend.

Furthermore, the knowledge of the impact of dividend, retained earnings on the share prices is also very useful for the corporate management of an organization in its decisions about the proportion of undistributed profits. The distribution of cash earning is perceived as an important indicator by the shareholder who helps them to judge the actual financial conditions and performance of the company. Company's decision of increasing the cash dividend is worked as an indication of the significant future growth of company's earnings for the investors. This inspires the investors to invest more in the stock of that particular company. On the contrary, if the company cuts off the cash dividends, a signal of declining performance of the company is passed through the market. It can prevent the investors to buy share of that particular company and this results into the downfall in the share prices of the company.

\section{References}

Bhattacharya, S. (1979). Imperfect Information, Dividend Policy, and "the Bird in the Hand" Fallacy. Bell Journal of Economics, 10, 259-270. http://dx.doi.org/10.2307/3003330

Bhattacharya, S. (1980). Nondissipative Signaling Structures and Dividend Policy. Quarterly Journal of Economics, 95, 1-24. http://dx.doi.org/10.2307/1885346

Brigham, E. F., \& Ehrhardt, M. C. (2005). Financial Management: Theory and Practice. Mason, Ohio: South-Western.

Easterbrook, F. H. (1984). Two Agency Costs Explanations of Dividends. American Economic Review, 74, 650-659.

Fama, E., Fisher, L., Jensen, M., \& Roll, R. (1969). The adjustment of stock prices to new information. International Economic Review, 10, 1-21. http://dx.doi.org/10.2307/2525569

Fisher G. R. (1961). Some Factors Influencing Share Prices. Economic Journal, 71, 121-141.

Friend, I., \& Puckett, M. (1964). Dividend and Stock Prices. American Economic Review, 54, 656-682.

Gordon, M. J. (1959). Dividends, Earnings, and Stock Prices. Review of Economics and Statistics, 41, 99-105.

Gordon, M. J. (1963). Optimal Investment and Financing Policy. Journal of Finance, 18, 264-272.

Jensen, M. C. (1986). Agency Costs of Free Cash Flow, Corporate Finance, and Takeovers. American Economic Review, 76, 323-329.

John, K., \& Williams, J. (1985). Dividends, Dillution, and Taxes: A Signalling Equilibrim. Journal of Finance, 40, 1053-1070. http://dx.doi.org/10.1111/j.1540-6261.1985.tb02363.x

Kale, J. R., \& Noe, T. H. (1990). Dividends, uncertainty and underwriting costs under asymmetric information. The Journal of Financial Research, 13, 265-277. http://dx.doi.org/10.1111/j.1475-6803.1990.tb00631.x

Khan, K. I., Amir, M., Qayyum, A., Nasir, A., \& Khan, M. I. (2011). Can dividend decisions affect the stock prices: A case of dividend paying companies of KSE. International Research Journal of Finance and Economics, 76, $67-74$.

Miller, M. H., \& Modigliani, F. (1961). Dividend Policy, Growth, and the Valuation of Shares. Journal of Business, 34, 411-433. http://dx.doi.org/10.1086/294442

Miller, M. H., \& Rock, K. (1985). Dividend Policy under Asymmetric Information. Journal of Finance, 40, 1031-1051. http://dx.doi.org/10.1111/j.1540-6261.1985.tb02362.x

Modigliani, F., \& Miller, M. H. (1959). The cost of capital, corporation finance and the theory of investment. American Economic Review, 49(4), 655-669.

Pettit, R. R. (1972). Dividend Announcements, Security Performance, and Capital Market Efficiency. Journal of Finance, 27, 993-1007. http://dx.doi.org/10.1111/j.1540-6261.1972.tb03018.x

Pradhan, R. S. (2003). Effects of Dividend on Common Stock Prices: The Nepalese evidence. Research in Nepalese Finance. Katmandu: Buddha Academic Enterprises.

Ross, S. A., Westerfield, R. W., Jordan, B. D., \& Roberts, G. S. (1999). Fundamentals of corporate finance: Canadian edition $\left(3^{\text {rd }}\right.$ ed.). Irwin. 